\title{
Law and sexual minority rights in the EU: navigating a political minefield
}

Book or Report Section

Accepted Version

Tryfonidou, A. (2020) Law and sexual minority rights in the EU: navigating a political minefield. In: Cardwell, P. J. and Grainger, M.-P. (eds.) Research Handbook on the Politics of EU Law. Edward Elgar, pp. 204-223. ISBN 9781788971270 Available at http://centaur.reading.ac.uk/92174/

It is advisable to refer to the publisher's version if you intend to cite from the work. See Guidance on citing.

Publisher: Edward Elgar

All outputs in CentAUR are protected by Intellectual Property Rights law, including copyright law. Copyright and IPR is retained by the creators or other copyright holders. Terms and conditions for use of this material are defined in the End User Agreement. 


\section{CentAUR}

Central Archive at the University of Reading

Reading's research outputs online 


\title{
Law and Sexual Minority Rights: Navigating a Political Minefield
}

\author{
Alina Tryfonidou*
}

School of Law, University of Reading

Email: a.tryfonidou@reading.ac.uk

ORCID: https://orcid.org/0000-0003-0639-0356

\begin{abstract}
Few issues incite as much controversy in contemporary politics as the recognition and protection of the rights of sexual minorities. The dominance of heterosexuality as the only legitimate form of sexual orientation and the silencing of all other discourses of sexuality have traditionally legitimised exclusionary laws and policies which completely ignored the existence of sexual minorities and relegated them to a second-rate position. In Europe, the first, tentative, steps towards the formation of an organised lesbian and gay liberation political movement were taken in the 1970s. Nonetheless, in the EU context, it took this political movement almost three decades before its efforts had begun to come to fruition, when the EU introduced its first legally binding instrument protecting sexual minorities from discrimination. This and other instruments have been interpreted by the CJEU in rulings which give mixed signals regarding the EU judiciary's commitment to the protection of the rights of persons with non-heterosexual sexualities. In fact, it is not merely the EU judiciary's stance on the rights of sexual minorities that has been mixed - overall, the EU's approach to this issue has been ambivalent, which reflects the pressures exerted by the Member States in this field. This is due to the fact that the rights of sexual minorities are a contested terrain where the struggles between the competing visions of 'Europeanness' and human rights, on the one hand, and national identity, morality, and tradition, on the other, take place. This chapter will have as its main aim to examine the reasons that lie behind the EU's ambivalent stance on the recognition and protection of the rights of sexual minorities. In particular, after analysing the protection currently offered to sexual minorities under EU law, the chapter will consider how the EU has navigated this political minefield and will seek to identify the main sites of interaction between law and politics when it comes to the recognition, respect, and protection of the rights of persons with non-heterosexual sexualities.
\end{abstract}

\footnotetext{
*I would like to thank Paul James Cardwell and Marie-Pierre Granger for their comments on an earlier draft of this article. All errors remain mine.
} 


\section{Keywords}

EU law; sexual minorities; fundamental rights; non-discrimination; sexual orientation; lesbian, gay, bisexual rights

\section{Introduction}

Few issues incite as much controversy in contemporary politics as the recognition and protection of the rights of sexual minorities. ${ }^{1}$ This is a complicated and sensitive matter which touches on issues relating to human rights, religion, culture, and tradition, as well as on constitutional principles such as equality, autonomy, and human dignity. It is no surprise, then, that views on all sides of the debate are overwhelmingly strong and fraught with tension.

Historically, persons with non-heterosexual sexualities were considered to be subjects of nonbelonging, 'the other', and, thus, judged as not worthy of rights. ${ }^{2}$ The dominance of heterosexuality as the only legitimate form of sexual orientation and the silencing of all other discourses of sexuality have traditionally legitimised exclusionary laws and policies which completely ignored the existence of sexual minorities and relegated them to a second-rate position.

In Europe, the first, tentative, steps towards the formation of an organised lesbian and gay liberation political movement were taken in the $1970 s,{ }^{3}$ following the Stonewall Riots in New York in 1969. ${ }^{4}$

\footnotetext{
${ }^{1}$ The term 'sexual minorities' should be taken here to refer to all persons who have a sexual orientation which is different from that of the majority population as the chapter will focus on the position of lesbian, gay and bisexual (LGB) persons. For the purposes of this chapter, the term 'sexual minority/ies' will, therefore, be used interchangeably with - and will be taken to be equivalent to - the terms 'LGB persons' and 'persons with non-heterosexual sexualities'.

${ }^{2}$ M Grigolo, 'Sexualities and the ECHR: Introducing the Universal Sexual Legal Subject' (2003) 14 European Journal of International Law 1023, 1024

${ }^{3}$ In Europe, 'homophile movements' had started been organised as early as in the 1860 s, however, new forms of (transnational) LGB activism which contested the more cautious approach of the earlier movements emerged in the 1970s - P Ayoub and D Paternotte, 'Europe and LGBT Rights: A Conflicted Relationship' in M Bosia, SM McEvoy and M Rahman (eds), The Oxford Handbook of Global LGBT and Sexual Diversity Politics (Oxford University Press 2019)

${ }^{4}$ For an account of the Stonewall Riots see D. Carter, Stonewall: The Riots that Sparked the Gay Revolution (St Martin's Press, 2004). For an excellent account of the history of the gay rights movement in the US see L Faderman, The Gay Revolution: The Story of the Struggle (Simon and Schuster 2015); and for an analysis of the role that NGOs have played in the development of an international approach to LGBT issues see E Aylward, 'Intergovernmental Organizations and Nongovernmental Organizations: The Development of an International Approach to LGBT Issues' in
} 
Nonetheless, in the EU context, it took this political movement almost three decades before its efforts had begun to come to fruition, when the EU introduced its first legally binding instrument protecting sexual minorities from discrimination. ${ }^{5}$ This and other instruments have been interpreted by the CJEU in rulings which give mixed signals regarding the EU judiciary's commitment to the protection of the rights of persons with non-heterosexual sexualities. In fact, it is not merely the EU judiciary's stance on the rights of sexual minorities that has been mixed - overall, the EU's approach to this issue has been ambivalent, which reflects the pressures exerted by the Member States in this field. This is due to the fact that the rights of sexual minorities are a contested terrain where the struggles between the competing visions of 'Europeanness' and human rights, on the one hand, and national identity, morality, and tradition, on the other, take place.

This chapter will have as its main aim to examine the reasons that lie behind the EU's ambivalent stance on the recognition and protection of the rights of sexual minorities. In particular, after analysing the protection currently offered to sexual minorities under EU law, the chapter will consider how the EU has navigated this political minefield and will seek to identify the main sites of interaction between law and politics when it comes to the recognition, respect, and protection of the rights of persons with non-heterosexual sexualities. The chapter will focus on one sexual minority group - lesbian, gay and bisexual (LGB) persons - as it is the sexual minority the rights of which have, to date, concerned the EU institutions the most.

\section{The Rights of Sexual Minorities under EU Law}

As human beings, LGB persons have the same human rights as everyone else. ${ }^{6}$ Hence, they have, inter alia, the right to be free from torture, the right to life, the right to private and family life, the right to freedom of assembly and association, and the right to freedom of expression. ${ }^{7}$ At the same time, as members of a sexual minority, LGB persons also need specific guarantees against discrimination, if they are to enjoy substantive equality with everyone else. This requires the promulgation of laws that prohibit discrimination based on sexual orientation, as well as the extension to sexual minorities of

\section{Bosia, SM McEvoy and M Rahman (eds), The Oxford Handbook of Global LGBT and Sexual} Diversity Politics (Oxford University Press 2019)

${ }^{5}$ Directive 2000/78 establishing a general framework for equal treatment in employment and occupation [2000] OJ L 180/22

${ }^{6}$ For a discussion on whether LGB rights should be elevated to the realm of human rights see NJ Beger, Tensions in the struggle for sexual minority rights in Europe: Que(e)rying Political Practices (Manchester University Press 2004), Chapter 4

${ }^{7}$ Obviously, LGB persons (like all others) can rely on human rights instruments and - in the EU context - on the general principles of EU law and the EU Charter of Fundamental Rights to claim respect for their human rights. In case a specific human right is refused to them on the basis of their sexual orientation they can rely on the prohibition of discrimination on the grounds of sexual orientation in conjunction with the provision protecting the said right in order to enforce their rights. 
access to numerous civil, social, and cultural rights granted (by default) to their heterosexual peers, such as the right to have their relationships legally recognised, and the right to found a family with a person of their choice and to be legally recognised jointly as the parents of a child. The question that will be explored in this section, therefore, is how far the EU has gone in recognising and safeguarding the rights of LGB persons.

What is today the EU, began its life in the 1950s in the form of three economically-oriented Communities: the ECSC, the EEC, and Euratom. The central aim of these Communities was to build a common market among the participating Member States and, thus, all Community policies were in some way related to the achievement of this economic aim. ${ }^{8}$ Hence, initially, discrimination was prohibited by the Community Treaties if it was such as to impede the achievement of their marketbuilding aims: this was judged to be the case with discrimination against nationals of - and products coming from - other Member States, which has always been prohibited under EU free movement law. ${ }^{9}$ In addition, a positively-worded provision was included in the founding Treaties, requiring equal pay for work of equal value between men and women - the current Article 157 TFEU - which proved to be the first building block of what has turned out to be one of the most successful EU policies: EU anti-discrimination law. ${ }^{10}$

As noted in the previous section, the first steps pushing for the recognition and protection of the rights of sexual minorities in the EU were taken in the 1970s. This led to a politicising process that facilitated public awareness and the mobilisation of large political debates around this matter. However, at first, EU law came empty-handed for persons with non-heterosexual sexualities as, until 1999, there was no binding EU legal instrument which either explicitly or implicitly protected their rights. ${ }^{11}$ At the same time, the CJEU appeared reticent (to put it mildly) in the first two cases where claims were brought by LGB persons claiming that they suffered discrimination by their employer because of their sexual orientation. In particular, it held that EU law did not, at the time, prohibit discrimination based on sexual orientation, nor did this form of discrimination amount to discrimination on the grounds of sex and thus was not prohibited by the EU instruments prohibiting the latter. Moreover, it was made clear that same-sex relationships were not equivalent to opposite-sex marriages or relationships outside

\footnotetext{
${ }^{8}$ For more on the history of the EU see L Van Middelaar, The Passage to Europe: How a Continent Became a Union (Yale University Press 2014)

${ }^{9} \mathrm{U}$ Belavusau and K Henrard, 'The Impact of the 2000 Equality Directives on EU Anti-Discrimination Law: Achievements and Pitfalls' in U Belavusau and K Henrard (eds), EU Anti-Discrimination Law Beyond Gender (Hart 2018) 6-8

${ }^{10} \mathrm{U}$ Belavusau and D Kochenov, 'Federalizing Legal Opportunities for LGBT Movement in the Growing EU' in K Slootmaeckers, H Touquet, and P Vermeersch (eds), The EU Enlargement and Gay Politics: The Impact of Eastern Enlargement on Rights, Activism and Prejudice (Palgrave Macmillan 2016) 77

${ }^{11}$ A Tryfonidou, 'The Impact of the Framework Equality Directive on the Protection of LGB Persons and Same-Sex Couples from Discrimination under EU law' in U Belavusau and K Henrard, EU AntiDiscrimination Law Beyond Gender (Hart 2018) 231-232
} 
marriage and, thus, the entitlements granted to persons who were in an opposite-sex marriage or relationship did not have to be extended to persons who were in a same-sex relationship. ${ }^{12}$

Of course, the above approach should be placed within the socio-political context in which the EU was operating at the time. By the end of the 1990s, the main achievement of the gay and lesbian rights movement in Europe was the decriminalisation of adult (male) consensual same-sex acts and this, in most instances, was merely a result of rulings of the European Court of Human Rights (ECtHR), rather than a deliberate political choice. ${ }^{13}$ Same-sex couples could formalise their relationships in only five EU Member States (Denmark, Sweden, Netherlands, France and Belgium), whilst same-sex marriage was not allowed anywhere in the world. A prohibition of discrimination on the grounds of sexual orientation was not included - explicitly - in any human rights instrument, whilst persons who were attracted to persons of the same sex were, still, viewed by the majority in most countries or even officially in some countries, as 'degenerates', 'sexual perverts' and 'mentally sick'.

Nonetheless, the gradual politicisation of EU anti-discrimination law from initially a tool in the process of creating a common market to a human rights instrument had, clearly, contributed to the protection of sexual minorities from discrimination under EU law. ${ }^{14}$ The foundations for this were placed in 1999, with the coming into force of the Treaty of Amsterdam, which introduced a new legal basis - what is now Article 19 TFEU - to give competence to the EU to make legislation prohibiting discrimination based on sex, racial or ethnic origin, religion or belief, disability, age or sexual orientation. ${ }^{15}$ This provision - which made the EC Treaty the first international agreement to explicitly make reference to discrimination based on sexual orientation - is what formed the legal basis for Directive 2000/78, which is still in force today and prohibits discrimination on a number of grounds, including sexual

\footnotetext{
${ }^{12}$ Case C-249/96 Grant v South-West Trains EU:C:1998:63; Joined Cases C-122 and 125/99 P D and Sweden v Council EU:C:2001:304
}

${ }^{13}$ App 7525/76, Dudgeon v UK, Judgment of the European Court of Human Rights, 22 October 1981, [1982] 4 EHRR 149; App 10581/83, Norris v Ireland, Judgment of the European Court of Human Rights, 26 October 1988 [1989] 13 EHRR 186; App 15070/89 Modinos v Cyprus, Judgment of the European Court of Human Rights, 22 April 1993 [1993] 16 EHRR 485

${ }^{14}$ A Tryfonidou, 'Discrimination on the Grounds of Sexual Orientation and Gender Identity' in S Vogenauer and S Weatherill (eds), General Principles of Law: European and Comparative Perspectives (Hart 2017). For an article which explains the reasons why putting LGBT issues on the agenda at the EU has been much more successful than at the UN see J Swiebel, 'Lesbian, gay, bisexual and transgender human rights: the search for an international strategy' (2009) 15 Contemporary Politics 19

${ }^{15}$ For an analysis on the steps that led to the introduction of this provision see $\mathrm{M}$ Bell and $\mathrm{L}$ Waddington, 'The 1996 Intergovernmental Conference and the Prospects of a Non-Discrimination Treaty Article' (1996) 25 Industrial Law Journal 320; M Mos, 'Of Gay Rights and Christmas Ornaments: The Political History of Sexual Orientation Non-discrimination in the Treaty of Amsterdam' (2014) 52 Journal of Common Market Studies 632 
orientation. ${ }^{16}$ The Directive, nonetheless, has a limited material scope - it only applies in the employment context - and for this reason there have been calls for another Directive which would prohibit discrimination on the same grounds, but in a broader number of areas (education, social protection (including healthcare and social security), social advantages, and access to goods and services (including housing)): this materialised in the form of a proposal for such a Directive in 2008, ${ }^{17}$ however, the opposition of a number of Member States has meant that this still remains in a state of legal limbo.

The interpretation of Directive 2000/78 has occupied the CJEU in the majority of its rulings involving claims by LGB persons and same-sex couples. In the first group of cases involving the Directive (Maruko, Römer, Hay), ${ }^{18}$ the Court held that in situations where a Member State has not opened marriage to opposite-sex couples but national legislation treats for a certain purpose (e.g. pensions) same-sex registered partnerships as equivalent to marriage, employers must extend - for that purpose - the treatment they afford to married couples to registered partners. If they do not, there is direct discrimination on the grounds of sexual orientation contrary to the Directive. It is interesting to note that in this trio of cases, the Court's approach has positively evolved, from giving, initially, a carte blanche to national courts to determine whether they would indeed extend the treatment afforded to (opposite-sex) married couples to (same-sex) registered partners, to one where the determination was taken away from the hands of national judges and placed in the hands of the CJEU. In the first two judgments (Maruko and Römer) the Court left it to the national court to assess whether for a specific purpose national law treated registered partnerships as equivalent to marriage, whereas in the last of these three judgments (Hay), the CJEU conducted the equivalence assessment itself. ${ }^{19}$

While in its first judgment (Asociaţia Accept) where Directive 2000/78 was relied on to defend an individual (as opposed to protecting the rights of same-sex couples) the CJEU appeared to adopt a much more positive approach to the protection of LGB rights, in a subsequent case involving the rights of same-sex couples under Directive 2000/78 (Parris), the Court seems to have backtracked a little,

\footnotetext{
${ }^{16}$ Directive 2000/78 (n 5). For an analysis of the prohibition of discrimination on the grounds of sexual orientation under the Directive see Tryfonidou, 'The Impact of the Framework Equality Directive on the Protection of LGB Persons and Same-Sex Couples from Discrimination under EU law' (n 11)

${ }^{17}$ Commission, 'Proposal for a Council Directive Implementing the Principle of Equal Treatment between Persons Irrespective of Religion or Belief, Disability, Age or Sexual Orientation' (2008) COM 426 final. This was accompanied by a Communication from the Commission to the European Parliament, the Council, the European Economic and Social Committee and the Committee of the Regions 'Non-Discrimination and Equal Opportunities: A renewed commitment' (2008) COM 420.

${ }^{18}$ Case C-267/06 Maruko EU:2008:179; Case C-147/08 Römer v Freie und Hansestadt Hamburg EU:C:2011:286; Case C-267/12 Hay ECLI:EU:C:2013:823

${ }^{19}$ For an analysis of the judgments see Tryfonidou, 'The Impact of the Framework Equality Directive on the Protection of LGB Persons and Same-Sex Couples from Discrimination under EU law' (n 11)
} 
and by hiding behind the screen of the national competence 'defence' it avoided to dip its toes into the (politically) uncomfortable waters of the legal recognition of same-sex relationships.

In Asociaţia Accept, ${ }^{20}$ the Court held that an action under Directive $2000 / 78$ can be brought by an NGO in the absence of an identifiable claimant. ${ }^{21}$ This is a principle previously established in a case ${ }^{22}$ involving the Race Equality Directive..$^{23}$ However, its application in cases involving discrimination on the grounds of sexual orientation is particularly important as it enables actions to be brought against homophobic employers without there being a need for LGB persons to 'come out' and reveal their sexual orientation at a time when they may not be ready or in circumstances that will make them suffer negative consequences such as social ostracism. This, in the words of Belavusau and Kochenov, revolutionises 'perspectives for future development of non-discrimination law in Europe' as it opens the way to 'strategic litigation either by a strong and genuinely independent equality body or by an autonomous human rights organization'. ${ }^{24}$ Moreover, the fact that the CJEU in this case held that mere homophobic statements based on a hypothetical, potential, scenario, suffice for a finding of a breach of the Directive (which shows that there is no need for an actual incident of a discriminatory practice to have taken place) is important in that it demonstrates that EU law does not merely aim at protecting the rights of specific LGB persons ex post, after they have been breached, but, also, more broadly, to prevent any actions which create a homophobic climate in society. ${ }^{25}$

In Parris, ${ }^{26}$ at issue was the compatibility with Directive 2000/78 of the requirement of an Irish pension scheme that in order for a member of that scheme to be able to designate his (same-sex or oppositesex) spouse or registered partner as the person entitled to receive a survivor's pension in the event of the member's death, their marriage or registered partnership should have been concluded before the latter turned 60. Ireland has allowed same-sex couples to enter into a registered partnership only from 1 January 2011 and same-sex registered partnerships contracted abroad can only be recognised from that date; same-sex marriage was introduced in Ireland in 2015, though the facts of the case arose before the introduction of same-sex marriage. The contested pension scheme requirement was, indeed, a universal condition that was applicable to both opposite-sex and same-sex couples.

\section{${ }^{20}$ Case C-81/12 Asociaţia Accept EU:C:2013:275}

${ }^{21}$ Article 9(2) of the Directive gives locus standi for organisations to represent disadvantaged groups either on behalf or in support of the complainant, with his or her approval, in any judicial and/or administrative procedure provided for the enforcement of obligations under this Directive.

${ }^{22}$ Case C-54/07 Feryn EU:C:2008:397

${ }^{23}$ Council Directive 2000/43/EC implementing the principle of equal treatment between persons irrespective of racial or ethnic origin [2000] OJ L180/22

${ }^{24}$ Belavusau and Kochenov, 'Federalizing Legal Opportunities for LGBT Movement in the Growing $\mathrm{EU}^{\prime}$ (n 10) 83

${ }^{25}$ For a full analysis of the judgment see U Belavusau, 'A Penalty Card for Homophobia from EU NonDiscrimination Law' (2015) 21 Columbia Journal of European Law 353

${ }^{26}$ Case C-443/15, Parris EU:C:2016:897 
However, the legal disability for LGB persons in Ireland to enter into a same-sex registered partnership until 2011 combined with the universal age condition for designating someone's registered partner or spouse as the person entitled to a survivor's pension, meant that a specific group of LGB persons (i.e. LGB persons born before 1951) would be disadvantaged by being unable under any circumstances to provide for their same-sex registered partners in case they pre-deceased them. Same-sex couples were under a legal disability as they could not formalise their relationship in Ireland until a specific date - hence, this placed them in a different position from their heterosexual peers who did not face a similar legal disability. By treating these two - differently situated - categories of persons in the same way, the contested requirement, therefore, led to discrimination against same-sex couples who suffered a disadvantage as a result of the fact that their legal disability was not taken into account when formulating the rules of the relevant pension scheme. The CJEU nonetheless dismissed the claim, noting that EU Member States are 'free to provide or not to provide for marriage for persons of the same sex, or an alternative form of legal recognition of their relationship, and, if they do so provide, to lay down the date from which such a marriage or alternative form is to have effect' ${ }^{\prime 27}$ Hence, the Court chose to wash its hands of the matter, allowing the perpetuation of discrimination on the grounds of sexual orientation caused by a pension scheme when regulating the financial consequences ensuing from the legal recognition of relationships. ${ }^{28}$

This (near-)obsession of the Court to show that it stays out of matters that touch on the legal recognition of same-sex relationships, was also evident more recently in the landmark Coman case, although, in this case the judgment yielded a positive result from the point of view of LGB rights. ${ }^{29}$ This case did not involve Directive 2000/78 but, rather, Directive 2004/38, ${ }^{30}$ which governs the right of EU citizens to move and reside in the territory of a Member State other than that of their nationality. The 2004 Directive gives the right to EU citizens who move to be joined or accompanied in the Member State of destination by their close family members; the latter are defined in Article 2(2) of the Directive and they include the 'spouse' of the Union citizen. The case therefore raised the question of whether the term 'spouse' for the purposes of the Directive should be interpreted to include, also, the samesex spouse of an EU citizen. This issue was, in fact, discussed during the drafting of the Directive, but - given the sensitivity of the matter - the EU legislature had chosen not to expressly extend family reunification rights to same-sex spouses, leaving this sensitive decision to judicial interpretation. ${ }^{31}$

\footnotetext{
${ }^{27}$ Ibid, para 59

${ }^{28}$ For a more detailed analysis of the case see Tryfonidou, 'Another failed opportunity for the effective protection of the rights of same-sex couples under EU law: Parris v Trinity College Dublin and Others' (2017) 2(2) Anti-Discrimination Law Review 83

${ }^{29}$ Case C-673/16, Coman EU:C:2018:385.

${ }^{30}$ Directive $2004 / 38$ on the right of citizens of the Union and their family members to move and reside freely within the territory of the Member States [2004] OJ L 158/77

${ }^{31}$ K. Lenaerts, 'Federalism and the Rule of Law' (2011) 33 Fordham International Law Journal 1338, 1355
} 
The Court, basing its conclusion purely on a functional, free-movement, argument held that Member States must grant family reunification rights to a Union citizen and his same-sex spouse, otherwise an obstacle to free movement will ensue. Accordingly, the result of the case is clearly positive, because it has established that married same-sex couples (at least those that have entered into a marriage in an EU Member State) can now be sure that they can move and reside with their same-sex spouse in all EU Member States and will be recognised as 'spouses' for the purpose of the grant of EU family reunification rights. Yet, this is as far as the judgment has gone. In particular, the judgment has left a number of important questions unanswered, whilst the Court has been at pains throughout its ruling to underline that it merely requires EU Member States to recognise same-sex marriages for the purpose of determining whether an EU citizen can claim family reunification rights when exercising EU free movement rights. What this implies is that for all other purposes, and especially for the purpose of determining whether they will introduce same-sex marriage in their territory, Member States remain completely free to make that determination. ${ }^{32}$

Finally, it should be noted that despite the advances made in some of the Court's rulings, especially in this last decade, until relatively recently there was no primary EU legislation provision which aimed to protect the rights of sexual minorities. Things, nonetheless, changed with the coming into force of the Treaty of Lisbon in 2009, which led to two important developments in this context. The first is that the Treaty of Lisbon inserted into the TFEU a new mainstreaming provision - Article 10 - which provides that in defining and implementing its policies and activities the Union shall aim to combat discrimination based on, inter alia, sexual orientation. This is hugely important since it ensures that the EU does not only provide reactive protection to sexual minorities once their rights have been violated, but it ensures that in all its activities it will take into account their rights. The second development is that the Treaty of Lisbon amended Article 6 TEU to provide that the EU Charter of Fundamental Rights (EUCFR or Charter) ${ }^{33}$ has the same legal value as the Treaties, meaning that the Charter is legally binding. This is important because Article 21 EUCFR provides that any discrimination based on, inter alia, sexual orientation shall be prohibited, in this way also reinforcing the argument that LGB rights are human rights. Moreover, an equality before the law clause is found in Article 20 EUCFR. These two provisions come as an important complement to the prohibition of sexual orientation discrimination laid down in Directive 2000/78. First, although Article 21 (like the Directive) prohibits discrimination on the grounds of sexual orientation, Article 20 can be used by LGB persons as a source of a positive right to be treated equally under the law with everyone else. Second, as noted earlier, the Directive has a limited material scope (it applies only in the employment context), whereas the Charter is not limited in this way, and thus Articles 20 and 21 can be relied on in situations outside the employment context. Nonetheless, the scope of application of the Charter is not unlimited either

\footnotetext{
${ }^{32}$ For comments on the case see A. Tryfonidou, 'The ECJ Recognises the Right of Same-Sex Spouses to Move Freely between EU Member States: The Coman Ruling' (2019) 44 European Law Review 662; D Kochenov and U Belavusau, 'Same-Sex Spouses: More Free Movement, but What about Marriage? The Romanian State, Sodom and Gomorrah, and the Case of Coman' (2019) 56 Common Market Law Review (forthcoming)

${ }^{33}$ Charter of Fundamental Rights of the European Union [2016] OJ C202/2 (consolidated version)
} 
- its Article 51 provides that it applies to all actions of the EU institutions, bodies, and agencies, and to Member States when they are implementing EU law. ${ }^{34}$

The CJEU has had, to date, the opportunity to interpret Article 21 EUCFR in a case involving discrimination on the grounds of sexual orientation only once, in the Léger case, where the French lifetime ban on blood donation by men who have had sex with men was contested for its compatibility with it. ${ }^{35}$ The Court's judgment in the case was rather disappointing in that the Court found that such a blanket ban may constitute discrimination on the grounds of sexual orientation, however, it went on to note that it can be justified by the need to achieve a high level of human health protection. As argued elsewhere, ${ }^{36}$ such a blanket lifetime ban imposed only on a specific sexual minority (gay and bisexual men) is not necessary for achieving a high level of health protection - there are other, less restrictive, ways to achieve this aim. Accordingly, it is disappointing that in this case the Court has not been bold enough to state clearly that a blanket, lifetime, ban on blood donations by gay and bisexual men is in no circumstances justified (untlik it did, more recently, in the Coman case seen above, where it did conduct the justification assessment itself). The Court's hands-off approach in this case in effect condoned a national measure which was based on deep-seated homophobia and on stereotypical misconceptions about gay and bisexual men. This is probably because it tried to avoid taking a clear stance on the matter, as it did not wish to be seen as interfering in a matter which is sensitive from the point of view of the Member States, given that the contested measure touched on matters of public health and sexuality, in relation to which a wide margin of appreciation is often left to the Member States.

This section aimed to take stock of the protection offered to date to sexual minorities under EU law, through binding provisions and through the most important rulings of the Court. A once-politically invisible sexual minority, LGB persons, have now been recognised as worthy of protection in the EU, mainly through the enforcement of their negative right to be free from discrimination on the basis of sexual orientation, which has been enshrined in primary and secondary EU legislation in the last couple of decades. Nonetheless, important gaps in (legislative) protection still remain - these being, mainly, that the prohibition of discrimination on the grounds of sexual orientation laid down by Directive 2000/78 is confined to the context of employment, and the same prohibition laid down by the EUCFR can only be relied on in situations which fall within the (ambiguously defined) scope of application of the EUCFR, as per its Article 51. At the same time, although there have been some positive CJEU rulings (such as Hay, Asociaţia Accept, and - to the extent that it has gone - Coman), there are still rulings (such as Parris and Léger) which demonstrate the Court's reticence to intervene and to explicitly require Member States to fully protect the rights of sexual minorities.

\footnotetext{
${ }^{34}$ For discussion see Tryfonidou, 'Discrimination on the Grounds of Sexual Orientation and Gender Identity' (n 14)

${ }^{35}$ Case C-528/13 Léger ECLI:EU:C:2015:288

${ }^{36} \mathrm{~A}$. Tryfonidou, 'The Léger ruling as another example of the ECJ's disappointingly reticent approach to the protection of the rights of LGB persons under EU law' (2016) 41 European Law Review 91
} 
It should be emphasised, nonetheless, that what the EU has provided, so far, in the legislative front for its LGB population is, mainly, the negative right to be free from discrimination. In other words, it has not legislated to (positively) extend to sexual minorities access to numerous civil, social, and cultural rights granted (by default) to persons who do not belong to a sexual minority. Moreover, in situations where the CJEU was given the opportunity to do so, it either did not take it (e.g. see Parris) or - if it did - it has been careful to ensure that the limits attached to its pronouncement were welldefined (e.g. Coman).

The above approach can, to a great extent, be attributable to the socio-political setting within which the EU and its top Court are operating. The next section will, therefore, be devoted to an examination of various aspects of this setting, which seem to be contributing to the EU's approach when it is confronted with claims for the protection of the rights of sexual minorities: why does the EU appear, in some instances, unable, at best, or unwilling, at worst, to protect the rights of sexual minorities?

\section{The EU Socio-Political Setting}

\subsection{The East/West divide and the ensuing legislative deadlock}

The EU boasts among its membership some of the most pioneering countries in the world for the protection of the rights of sexual minorities and LGB rights in particular. Denmark was the first country in the world to open registered partnerships to same-sex couples in 1989, whilst Netherlands - one of the founding EU Member States - was the first country to introduce same-sex marriage, in 2001. In fact, until 2004, the EU was mainly comprised of States which - at the moment - are amongst the most progressive in the world for the protection of LGB rights. These pre-2004 EU enlargement States currently not only prohibit discrimination on the grounds of sexual orientation but, also, have extended many of the civil, social, and cultural, rights granted (by default) to persons who do not belong to a sexual minority, to LGB persons. ${ }^{37}$

On the other hand, as a result of its three most recent - eastwards - enlargements (2004, 2007, and 2013), ${ }^{38}$ the EU now has a much more diverse membership and includes states at both ends of the

\footnotetext{
${ }^{37}$ Of the pre-2004 EU enlargement States, all of them provide legal recognition to same-sex relationships, and all but two (Greece and Italy) allow same-sex couples to jointly become parents and to be legally recognised as such.

${ }^{38}$ For an analysis of the evolution of LGBT rights within the context of the EU's enlargement policy see K Slootmaeckers and H.Touquet, 'The Co-evolution of EU's Eastern Enlargement and LGBT Politics: An Ever Gayer Union?' in K Slootmaeckers, H Touquet, and P Vermeersch (eds), The EU Enlargement and Gay Politics: The Impact of Eastern Enlargement on Rights, Activism and Prejudice (Palgrave Macmillan 2016)
} 
spectrum of LGB egalitarianism. ${ }^{39}$ And although all EU Member States have decriminalised same-sex activities, have equalised the age of consent, and - implementing Directive 2000/78 - have introduced legislation prohibiting discrimination on the grounds of sexual orientation (at least) in the area of employment, there are currently six Eastern EU Member States that do not make any provision for the legal recognition of same-sex relationships, ${ }^{40}$ and seven which maintain a constitutional ban on same-sex marriage. ${ }^{41}$ In these EU Member States where social change has not yet been achieved and there is, still, widespread homophobia, political leaders have, often, gained political capital by publicly displaying homophobia and marginalising sexual minorities with calls to 'the defence of the nation' ${ }^{42}$ In addition, these Member States often have high levels of religiosity, ${ }^{43}$ and thus the actions and rhetoric of religious institutions act as powerful counter-mobilisers against LGB rights. ${ }^{44}$ Eastern EU Member States often view issues concerning sexual minorities as an imposition of 'Western values', which may clash with their norms and values which, allegedly, are more attached to tradition, religion, and the (nuclear) family as the foundation of society. ${ }^{45}$

But how does this lack of homogeneity in the EU's membership affect the EU's stance on the protection of the rights of sexual minorities?

${ }^{39}$ Some have even argued that the EU's enlargement has contributed to the concretisation of the East-West divide in relation to the protection of sexual minorities. See, for instance, the essays in $\mathrm{R}$ Kulpa and J Mizielinska (eds), De-centring Western Sexualities: Central and Eastern European Perspectives (Ashgate 2011)

${ }^{40}$ Bulgaria, Latvia, Lithuania, Poland, Romania, Slovakia

${ }^{41}$ Bulgaria, Croatia, Hungary, Latvia, Lithuania, Poland, Slovakia. For literature regarding the legal recognition of same-sex relationships in the EU see, inter alia, A Tryfonidou, 'EU Free Movement Law and the Legal Recognition of Same-Sex Relationships: The Case for Mutual Recognition' (2015) 21 Columbia Journal of European Law 195; D Kochenov, 'On Options of Citizens and Moral Choices of States: Gays and European Federalism' (2009) 33 Fordham International Law Journal 156; S Titshaw, 'Same-Sex Spouses Lost in Translation? How to Interpret "Spouse" in the EU Family Migration Directives' (2016) 34 Boston University International Law Journal 45

${ }^{42}$ RCM Mole, 'Nationalism and Homophobia in Central and Eastern Europe' in K Slootmaeckers, H Touquet, and P Vermeersch (eds), The EU Enlargement and Gay Politics: The Impact of Eastern Enlargement on Rights, Activism and Prejudice (Palgrave Macmillan 2016)

${ }^{43}$ For an article exploring the role of religion (and cultural context) in shaping attitudes towards nonheterosexual sexual orientations see A Adamczyk and C Pitt, 'Shaping attitudes about homosexuality: The role of religion and cultural context' (2009) 38 Social Science Research 338

${ }^{44}$ RCM Mole, 'Nationalism and Homophobia in Central and Eastern Europe' (n 42) 108-109. For an analysis of the factors that account for different levels of legal recognition of sexual minorities across EU Member States see P Ayoub, 'EU Law as an (In)Direct Source of LGB Rights across Europe' in U Belavusau and K Henrard, EU Anti-Discrimination Law Beyond Gender (Hart 2018)

${ }^{45}$ Ayoub and Paternotte, 'Europe and LGBT Rights' (n 3) 
Article 19 TFEU, which - as seen earlier - gives the EU its power to make legislation prohibiting discrimination on the grounds of sexual orientation, requires unanimity in the Council for a proposal to be passed into law. Given that any legislation which seeks to advance the rights of sexual minorities will need to be based (either wholly or partly) on this legal basis, this means that with regards to the rights of sexual minorities, there is - effectively - a legislative deadlock at EU level. Taking into account the position of at least a handful of the EU's current Member States towards issues involving sexual minorities, it is certain that at the moment the required unanimity cannot be achieved. This condemns to a gridlock any attempts by the EU to legislate in a way which adds to the protection offered to LGB persons at EU level. In fact, this may be the main reason behind the EU's determination in recent years to adopt (merely) soft law measures which aim to establish a benchmark for the protection of the rights of LGB persons, most notably the EU Commission's List of Actions to Advance LGBTI Equality. ${ }^{46}$

In any event, if the general passerelle clause ${ }^{47}$ in Article 48(7) TEU is activated (as recently suggested by the Commission), ${ }^{48}$ this will mean that legislation based on Article 19 TFEU will only require qualified majority voting in the Council (meaning that a single Member State or, even, a small minority of Member States, will no longer be able to block a proposal). Moreover, if the option of extending the ordinary legislative procedure to this legal base is also chosen, this will make the European Parliament - the most pro-LGB institution ${ }^{49}$ - a real co-legislator with the Council when it comes to proposals that seek to combat discrimination. Such moves would make it more likely that legislation

\footnotetext{
${ }^{46}$ List of actions by the Commission to advance LGBTI equality (2015) available at $<$ https://ec.europa.eu/info/sites/info/files/Igbti-actionlist-dg-just en.pdf> accessed 25 July 2019. The Commissioner for Justice, Consumers and Gender Equality (at the time), Verra Jourová, presented the list of actions to advance LGBTI equality to the Council and the European Parliament in December 2015, which was the Commission's response to a European Parliament Resolution and a joint call from Member States to step up efforts to combat discrimination based on sexual orientation and gender identity. The Council conclusions on LGBTI equality in June 2016 required the Commission to report annually on the implementation of the list of actions.
}

${ }^{47}$ This clause enables the European Council, acting by unanimity and after obtaining the consent of the European Parliament, to adopt a decision authorising the Council to act by a qualified majority in an area for which unanimity is normally required, or to adopt legislative acts with the ordinary legislative procedure (which makes the European Parliament a co-legislator) in areas for which the requirement is to use a special legislative procedure (where the Council is the sole legislator).

${ }^{48}$ Communication from the Commission to the European Parliament, the European Council, the Council, the European Economic and Social Committee and the Committee of the Regions: 'More efficient decision-making in social policy: Identification of areas for an enhanced move to qualified majority voting' $\operatorname{COM(2019)} 186$ final available

$<$ https://ec.europa.eu/social/main.jsp?langld=en\&catld=89\&newsld=9351\&furtherNews=yes> accessed 26 June 2019

${ }^{49}$ LM Ames, 'Beyond Gay Paree: What Does the Enlargement of the European Union mean for SameSex Partners?' (2004) 18 Emory International Law Review 503, 525-527; M Mos, 'Of Gay Rights and Christmas Ornaments' (n 15) 636-641 
which protects the rights of sexual minorities is adopted, including, of course, the pending proposal for an Equal Treatment Directive, ${ }^{50}$ which, as noted earlier, is currently blocked in the Council.

Furthermore, like in all international/supranational organisations, the law-making process in the EU is heavily politicised, with vote trading and political games being rife. Accordingly, most pieces of legislation - including legislation which touches directly or indirectly on issues concerning sexual minorities - constitute a compromise and the result of a give and take by the Member States. ${ }^{51}$ In the specific context of the rights of sexual minorities, this process of vote trading often results in a 'dilution' of the protection afforded to LGB persons (if any provision for such protection is, in fact, made!), since this is an issue that comes relatively low in the agenda of Member States. Accordingly, even EU Member States that have been pioneers in advancing the rights of sexual minorities in their territory, may not push for inclusion of provisions which safeguard the rights of sexual minorities in EU legislation. To do so might compromise their interests in matters which are, traditionally, higher up on their agenda and will, thus, have economic or political costs for them. ${ }^{52}$

\subsection{The Enforceability Conundrum}

The protection of human rights is part of the Copenhagen political criteria introduced in 1993, which candidate countries must satisfy in order to be allowed to join the EU. As explained by Slootmaeckers and Touquet, although the Copenhagen criteria do not explicitly mention $L G B(T)$ rights, ${ }^{53}$ they have brought such rights within the scope of the accession process, via the requirement that the candidate countries are members of the Council of Europe. ${ }^{54}$ This has, in fact, proven to be an effective way for the EU to exert pressure on some of its current members - prior to their accession - to amend their laws in a way which is compliant with basic human rights obligations regarding the protection of LGB rights. ${ }^{55}$ In fact, as argued by other commentators, the pressure that the EU can put to aspiring

${ }^{50}$ Commission, 'Proposal for a Council Directive Implementing the Principle of Equal Treatment between Persons Irrespective of Religion or Belief, Disability, Age or Sexual Orientation' (n 17)

${ }^{51}$ See, for instance, the examples noted in Beger, Tensions in the struggle for sexual minority rights in Europe, (n 6) 23-24

${ }^{52}$ Such an example is the (op)position of the Dutch government towards the inclusion of sexual orientation in - what is now - Article 19 TFEU during the negotiations for the Treaty of Amsterdam.

${ }^{53}$ Note, however, that LGBT issues were for the first time in 2013 explicitly identified as a key issue in the context of enlargement by the Commission in its Communication 'Enlargement Strategy and Main Challenges 2013-2014' (2012) COM 700

<http://publications.europa.eu/resource/cellar/3cccdda3-37ee-11e3-a86c-

01aa75ed71a1.0002.04/DOC 1> accessed 12 July 2019

${ }^{54}$ Slootmaeckers and Touquet, 'The Co-evolution of EU's Eastern Enlargement and LGBT Politics' (n 38) 24

${ }^{55}$ For an analysis of the protection of LGB rights under the ECHR see P Johnson, Homosexuality and the European Court of Human Rights (Palgrave 2014); DA Gonzalez-Salzberg, Sexuality \& 
Member States is much more powerful than the ability it has to require them to comply with their membership obligations, once they become members, ${ }^{56}$ and this, often, results in double standards being applied, whereby candidate countries are required to abolish provisions which are discriminatory against sexual minorities, even though some existing EU Member States have not done so. ${ }^{57}$ The EU has, also, been criticised for applying double standards, when its approach towards the protection of sexual minorities within EU Member States is compared with its external action promoting the rights of sexual minorities internationally. ${ }^{58}$

As seen in the previous section, there is primary and secondary EU legislation which protects sexual minorities from discrimination though, admittedly, there are still lots of gaps in the protection afforded to LGB persons and same-sex couples under EU law. National implementation of the EU's anti-discrimination legislation, nonetheless, is quite problematic ${ }^{59}$ and varies greatly between Member States. ${ }^{60}$ Moreover, although it is clear ${ }^{61}$ that all EU legislation needs to be read in a way

Transsexuality under the European Convention on Human Rights: A Queer Reading of Human Rights Law (Hart 2019)

${ }^{56} \mathrm{C}$ O'Dwyer, 'From Conditionality to Persuasion? Europeanization and the Rights of Sexual Minorities in Post-Accession Poland' (2010) 32 European Integration 229; M Kristoffersson, B van Roozendaal and L Poghosyan, 'European Integration and LGBTI Activism: Partners in Realising Change?' in K. Slootmaeckers, H. Touquet, and P. Vermeersch (eds), The EU Enlargement and Gay Politics: The Impact of Eastern Enlargement on Rights, Activism and Prejudice (Palgrave Macmillan 2016) 54

${ }^{57}$ Kristoffersson, van Roozendaal and Poghosyan, 'European Integration and LGBTI Activism' (n 56) 50. Cardwell has noted that CFSP Declarations - to which candidate other associated countries are invited to align too - have consistently required protection of minority rights as an expression of the EU's values - see PJ Cardwell, 'Values in the European Union's Foreign Policy: An Analysis and Assessment of CFSP Declarations' (2016) 21 European Foreign Affairs Review 601

${ }^{58}$ See, for instance, the Foreign Affairs Council's Guidelines to Promote and Protect the Enjoyment of All Human Rights by Lesbian, Gay, Bisexual, Transgender and Intersex (LGBTI) Persons (2013) <https://www.consilium.europa.eu/uedocs/cms Data/docs/pressdata/EN/foraff/137584.pdf> accessed 25 July 2019

${ }^{59}$ B Havelková, 'Resistance to Anti-Discrimination Law in Central and Eastern Europe' (2016) 16 German Law Journal 627

${ }^{60} \mathrm{See}$, for instance, Motion for a European Parliament Resolution on application of Council Directive 2000/78 of 27 November 2000 establishing a general framework for equal treatment in employment and occupation (2015/20116(INI)) <http://www.europarl.europa.eu/doceo/document/A-8-20160225_EN.html\#_part1_ref29> accessed 25 July 2019. See, also, J Tymowski, 'The Employment Equality Directive: European Implementation Assessment' (2016) European Parliamentary Research Service <http://www.europarl.europa.eu/RegData/etudes/STUD/2016/536346/EPRS STU(2016)536346 EN .pdf $>$ accessed 25 July 2019

${ }^{61}$ See, inter alia, Articles 2 TEU, 6 TEU, 21 EUCFR and 10 TFEU 
which respects fundamental human rights, some EU Member States still insist on implementing pieces of EU legislation in a way which disregards the rights of sexual minorities. An obvious example is the right of LGB Union citizens to move between EU Member States and claim family reunification rights with their same-sex spouses/registered partners/partners, under Directive 2004/38. ${ }^{62}$ As seen earlier, this issue has recently been (partly) resolved as a result of the Coman ruling, where the Court held that married same-sex couples can move and be recognised as such for the purpose of the grant of family reunification rights, in any EU Member State, irrespective of whether that Member State has opened marriage to same-sex couples in its territory. Whether all EU Member States - especially those that maintain a constitutional ban on same-sex marriage - will implement this ruling, remains to be seen. ${ }^{63}$

The main difficulty in this context is that - as is the case, generally, with supranational/international organisations ${ }^{64}$ - there are limited possibilities for enforcing EU law and, thus, implementation of EU legislation at national level is mostly dependent on moral and political pressure and on the goodwill of the Member States themselves. When an EU Member State fails to comply with its obligations under EU law, a private enforcement action (before a national court) can, in most instances, be brought by an individual relying on direct effect. In addition - or alternatively - the Commission can bring an enforcement action before the CJEU under Article 258 TFEU, though - for political reasons ${ }^{65}$ - this is unlikely to be done for issues that are politically contested, such as LGB rights. In any event, even when a successful (private or public enforcement) action is brought, this does not necessarily mean that the recalcitrant Member State will respond by bringing its legislation and/or actions in line with its membership obligations, ${ }^{66}$ since the Union institutions have no means of direct enforcement of CJEU judgments or national court judgments which find a Member State in violation of EU law. ${ }^{67}$ Moreover, Article 7 TEU can only be used as a last resort in a political emergency such as a military coup, and to date the EU has not used it in situations involving politically sensitive matters such as the protection of the rights of sexual minorities. Accordingly, the only realistic solution may be for the EU institutions, individual Member States, and advocacy and minority rights groups, to resort to the

62 Other EU instruments which have implications for the rights of LGB persons are Directive 2003/86 on the right to family reunification [2003] OJ L 251/12 and Directive 2011/95 on standards for the qualification of third-country nationals or stateless persons as beneficiaries of international protection, for a uniform status for refugees or for persons eligible for subsidiary protection, and for the content of the protection granted [2011] OJ L 337/9

${ }^{63}$ A. Avetisyan and J. Teoh, 'Together we can make the Coman judgment a reality: the freedom of movement of same-sex couples across the EU' (ILGA Europe blog, 28 March 2019) $<$ https://www.ilga-europe.org/blog/together-we-can-make-coman-judgment-reality $>$ accessed 25 July 2019

${ }^{64}$ R. Freedman, Failing to Protect: The UN and the Politicisation of Human Rights (Hurst and Company 2014)

${ }^{65}$ P. Craig, 'Once Upon a Time in the West: Direct Effect and the Federalization of EEC Law' (1992) 12 Oxford Journal of Legal Studies 453, 454-457

${ }^{66}$ Ibid 456

${ }^{67}$ TC Hartley, The Foundations of European Union Law (Oxford University Press 2010) 345 
strategy of exerting legal and political pressure on specific Member States. For instance, more powerful Member States may threaten with political or economic sanctions weaker Member States that refuse to comply with their obligations under EU law which affect the rights of sexual minorities.

It is not surprising, therefore, that the EU has not taken big legislative steps seeking to ensure the protection of sexual minorities and that the CJEU has been rather reserved in its rulings involving the enforcement of LGB rights: being aware that there are some EU Member States that are strongly opposed to protecting or, even, simply respecting, the rights of sexual minorities, the EU legislature and the CJEU tend to take a middle position and adopt small steps which are less likely to raise the fervent objection of the more hard-core homophobic Member States. In this way, the EU saves face by imposing obligations which are more likely to be (fully or partly) implemented by all Member States, whilst it ensures that (small) advances in the protection of the rights of sexual minorities are not stifled by Member States that would oppose more significant changes.

\section{The Competence Issue}

It is well-known that in the post-World War II era, with the advent of globalisation and the increased need for international cooperation, nation states are no longer fully sovereign. Their membership of international organisations means that their freedom to legislate and take action is limited by their international obligations. This is the case, also, with EU Member States. Although they continue to be sovereign states, their freedom to legislate in situations where the EU does not have competence or in situations where it is decided - applying the principle of subsidiarity - that the said objective can be sufficiently achieved at national level is, still, curtailed by the legal obligations they have as EU Member States. Accordingly, the tendency of some Member States is to call for less interference by the EU and to argue that the EU's competence and the scope of EU law is more limited than the EU presents it to be. This is what lies behind arguments that the EU institutions - including the CJEU have led to 'competence creep' and that the scope of EU law has been inappropriately expanded to govern situations which have little - if any - connection with the EU's objectives. ${ }^{68}$

Naturally, 'lack of competence' arguments are likely to be used by EU Member States when they are objecting to legislative proposals seeking to advance the rights of sexual (or other) minorities. The likelihood that such arguments will be used against EU actions in situations taking forward the protection that the EU offers to sexual minorities is, in fact, possibly one of the factors that is taken into account by the EU and/or the CJEU, in instances where their approach towards protecting the rights of sexual minorities appears wanting. In other words, the fear of being accused of acting ultra vires or of over-extending the scope of EU law in situations which are unrelated to the EU's competences and objectives makes the EU and its institutions - including its judiciary - doubly cautious in situations which involve sensitive matters such as the rights of sexual minorities. This is an

\footnotetext{
${ }^{68}$ S Weatherill, 'Competence Creep and Competence Control' (2004) 23 Yearbook of European Law 1; G Davies, 'Subsidiarity: the wrong idea, in the wrong place, at the wrong time' (2006) 43 Common Market Law Review 63; ADL Knook, 'The Court, the Charter, and the vertical division of powers in the European Union' (2005) 42 Common Market Law Review 367
} 
apt demonstration of the politics of the law and of the fact that law-making is not existing in a vacuum but is always affected by the socio-political context which prevails at the relevant time. For instance, it is well-known that the EU does not have competence in the family law field but, merely, a limited power to adopt harmonising measures on family law with cross-border implications. ${ }^{69}$ It has, therefore, been left to the Member States to decide what legal recognition, if any, will be given to same-sex couples in their territory. ${ }^{70}$ Similarly, it is left to EU Member States to decide whether they will allow same-sex couples in their territory to become de facto parents and to establish a family under the law by being legally recognised as the joint parents of their children. ${ }^{71}$ Accordingly, it is clear that the EU does not have the competence to legislate on the above issues and to extend access to the above rights to same-sex couples.

Of course, even when they act in areas that fall within their exclusive competence, Member States must act in a way which respects their obligations under EU law. ${ }^{72}$ This is why, although the EU does not have competence in relation to many issues that touch on the rights of sexual minorities, EU law is often invoked, the most obvious example here being the cross-border legal recognition of same-sex relationships in situations where EU citizens have exercised their right to free movement, as per the Coman scenario. In these cases, EU law does affect the rights of sexual minorities, albeit only incidentally, because if EU law protection is not granted, this will lead to the breach of EU law provisions which do not - specifically - seek to protect the rights of sexual minorities, such as the EU free movement provisions. This explains the Court's anxiousness in the Coman case, to emphasise that the ruling is not the European Obergefell, ${ }^{73}$ which led to marriage equality in the US: Coman, merely, requires EU Member States not to obstruct the free movement rights that LGB Union citizens - as all Union citizens - enjoy under EU law. Accordingly, with Coman the EU has gone as far as it can with regards to the issue of marriage equality, whilst respecting the limits to its competence.

Moreover, even in cases like Léger, where it made it clear that the contested national measure was, indeed, discriminatory against the members of a specific sexual minority, but left it to the national court to decide whether the measure was nonetheless justified, the CJEU may be excused for taking a more 'light-touch' approach towards justifications, possibly being aware that the recalcitrant State was, already, taking steps to amend the contested legislation, and, thus, to remove the discrimination that was challenged. ${ }^{74}$ In other words, it is quite usual in instances that require complex assessments

${ }^{69}$ Article 81(3) TFEU - such measures require the unanimous approval of the Council.

${ }^{70}$ This has been repeatedly noted by the ECJ in a number of its judgments - see, for instance, Maruko, para 59; Parris, para. 59; Coman, para. 37

${ }^{71}$ See A. Tryfonidou, 'EU Free Movement Law and the Children of Rainbow Families: Children of a Lesser God?' (2019) 38 Yearbook of European Law (forthcoming)

${ }^{72}$ Case C-148/02, Garcia Avello EU:C:2003:539, para. 25; Case C-353/06, Grunkin and Paul EU:C:2008:559, para 16; Case C-438/14, Bogendorff von Wolffersdorff EU:C:2016:401, para 32.

${ }^{73}$ Obergefell v Hodges 576 US (2015)

${ }^{74}$ Even prior to the delivery of the judgment, France had begun considering whether it should reduce the deferral period - the French legislation was amended shortly after the delivery of the 
and policy choices for the Court to scrutinise national measures quite lightly, leaving it to national courts to have the final say as to whether they can be justified, ${ }^{75}$ as a wide margin of appreciation is left to the Member States with regards to such sensitive matters. After all, policy choices are not to be made by a supranational, unelected, body but, rather, they are a task for political institutions that have democratic legitimacy.

Yet, it should be remembered that although the issues concerning LGB persons are, indeed, sensitive matters that require policy choices to be made which are, thus, better suited for a body with democratic legitimacy, at the same time, they involve the fundamental human rights of a sexual minority. Accordingly, although national legislatures and courts are better placed than a supranational court or a supranational legislature to evaluate local needs and conditions, nonetheless, in instances where it is clear that the fundamental human rights of a sexual minority are violated, the supranational institutions should be bold enough to say so. ${ }^{76}$ This is especially so given that the EU identifies and presents itself as an organisation founded on, inter alia, the values of respect for human dignity, freedom, equality, and respect for human rights, ${ }^{77}$ and has among its aims, to promote these values both internally and externally and to combat social exclusion and discrimination. ${ }^{78}$ Accordingly, it must make it clear that it has zero-tolerance for the violation of any of these values, even if this will in certain contexts displease specific Member States.

\section{Conclusion}

Although the EU has been quite successful in ensuring that every EU Member State prohibits discrimination on the grounds of sexual orientation in the employment field, the protection it affords to sexual minorities in other areas of their lives ranges from very limited (legal recognition of samesex relationships in cross-border situations) to none at all (e.g. parenting), whereby Member State practices designed to oppress and disrespect LGB persons are tolerated. Yet, it should be underlined

CJEU judgment and gay and bisexual men in France can now donate blood if they have abstained from sex with other males for one year; in 2020, the legislation will again be amended to reduce the deferral period to four months (France24, 17 July 2019) <https://www. france24.com/en/20190717france-12-month-deferral-blood-donations-homosexual-gay-men-four-months $>$ accessed 25 July 2019

${ }^{75}$ This light-touch approach has been applied by the Court also when engaging in judicial review of EU legislation in sensitive areas - J Kokott and C Sobotta, 'The Evolution of the Principle of Proportionality in EU Law - Towards an Anticipative Understanding?' in S Vogenauer and S Weatherill (eds), General Principles of Law: European and Comparative Perspectives (Hart 2017) 169171

${ }^{76}$ A. Tryfonidou, 'The Federal Implications of the Transformation of the Market Freedoms into Sources of Fundamental Rights for the Union Citizen' in D Kochenov (ed), EU Citizenship and Federalism: The Role of Rights (Cambridge University Press 2017) 319-325

${ }^{77}$ Article 2 TEU.

${ }^{78}$ Article 3 TEU. Ayoub and Paternotte, 'Europe and LGBT Rights' (n 3) 
that the EU's contribution towards the protection and promotion of the rights of sexual minorities is not, merely, what we see on paper. The EU has increased the visibility and legitimacy of LGBT issues, which now form part of the European values, and has constructed a basic core of 'minimum "European" standards of sexual rights'. ${ }^{79}$ Moreover, as explained by Belavusau and Kochenov, in matters where such minimum European standards are not available or sufficient, the EU provides an exit option for those who are unhappy in their home state. ${ }^{80}$

It is, of course, true, that the EU's acquis on the rights of sexual minorities is, still, rather limited. However, this can be explained by the socio-political context within which the EU is operating and this chapter had as its aim, exactly, to place the EU's (ambivalent) approach towards persons with nonheterosexual sexualities within this socio-political context. First, it was seen that the lack of homogeneity in the current EU membership coupled with the requirement of unanimity laid down by the legal basis which gives power to the EU to make legislation to eradicate discrimination on, inter alia, the grounds of sexual orientation, means that it is difficult (if not impossible) to make further EU legislation advancing the rights of persons with non-heterosexual sexualities. Second, it was explained that homophobic EU Member States relegate LGB rights to the realm of culture and tradition and argue that the protection of sexual minorities is a matter which falls outside EU competence and, thus, the EU should stay out of it. Finally, it was seen that the EU - like all supranational/international organisations - has very limited opportunities for direct enforcement of its legislation. For these reasons, when it comes to the rights of sexual minorities, the EU legislature and the CJEU have tended to take a middle position and adopt small steps which are less likely to raise the fervent objection of the more hard-core homophobic Member States and which are more likely to be implemented at national level. Nonetheless, although the above position of the EU legislature and judiciary can be understood when placed within the socio-political context within which the EU is currently operating, at the same time, it should not be forgotten that since sexual minorities are comprised of human beings who - as such - enjoy fundamental human rights, the latter must be protected and respected in all instances apart from when an interference is judged to be legitimate and justified. EU law cannot wait for the majority to accept sexual minorities as worthy of protection but should, rather, protect sexual minorities exactly in order to demonstrate to the majority that they are worthy of respect and protection.

\footnotetext{
${ }^{79}$ U. Belavusau, 'EU Sexual Citizenship: Sex Beyond the Internal Market' in D. Kochenov (ed), EU Citizenship and Federalism: The Role of Rights (Cambridge University Press 2017) 440

${ }^{80}$ Belavusau and Kochenov, 'Federalizing Legal Opportunities for LGBT Movement in the Growing EU' (n 10) 71
} 